\title{
Building blocks for sustainable food systems
}

\author{
Book review by Molly D. Anderson*
}

College of the Atlantic

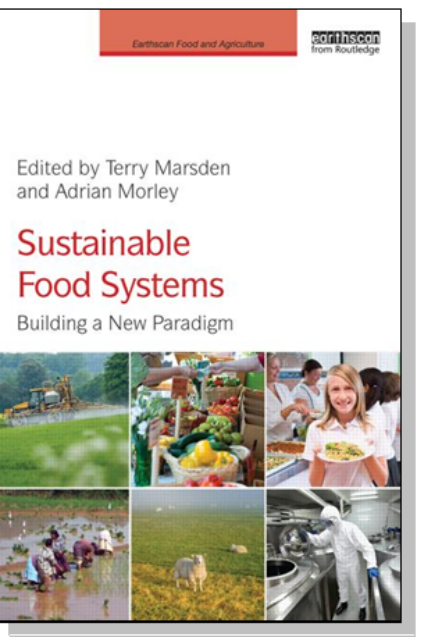

\section{Review of Sustainable Food Systems: Building a New Paradigm, edited by Terry Marsden and Adrian Morley}

\author{
Marsden, T., \& Morley, A. (Eds.). (2014). Sustainable Food Systems: Building a \\ New Paradigm. Abingdon, UK, and New York: Routledge. Available as \\ hardcover and Kindle eBook; 256 pages. Publisher's website: \\ http://www.routledge.com/books/details/9780415639545/
}

Citation: Anderson, M. D. (2014). Building blocks for sustainable food systems [Book review]. Journal of Agriculture, Food Systems, and Community Development. Advance online publication. http://dx.doi.org/10.5304/jafscd.2014.051.009

Copyright (C) 2014 by New Leaf Associates, Inc.

$\mathrm{T}$ his is an ambitious book; it is not a light undertaking to build a "new paradigm" for sustainable food systems. The authors and editors succeed in notable ways, although there are questions about the applicability of the framework and analysis they present outside Western Europe, where most of the contributors are based, and beyond the concerns and activities of relatively privileged people in that region.

In the final chapter, Marsden describes this "new paradigm" as one of "social and economic creativity and care...that shines a strong light upon the existing unsustainable conditions... It needs to be a paradigm that starts as much with the critical social and public priorities as with the economic;

* Molly D. Anderson holds the Partridge Chair in Food \& Sustainable Agriculture Systems at College of the Atlantic, where she teaches on food security, food policy, and sustainability. She can be contacted at College of the Atlantic, 105 Eden Street, Bar Harbor, Maine 04609 USA; manderson@coa.edu and it needs to be able to shape the latter through imagining and designing more effective...statebased interventions and actions" (p. 206). Chapters in the book are conceived as "key building blocks" of this paradigm, such as regulation and governance mechanisms, public procurement, the design of urban food systems, sustainable supply chains, the rural-urban nexus, biosecurity risks, and animal welfare. Chapters describe work conducted over the past 10 years through Cardiff University's Centre for Business Relationships, Accountability, Sustainability \& Society, which Marsden directs.

The first chapter lays out some of the major developments and debates in the conjoined fields of food security and sustainability, attempting to explain why these have not been explicitly considered together. This discussion takes the reader through imperial food regimes, productivism, intensification and neoproductivism, as they played out against an unfolding environmental crisis. Marsden and Morley ask what comes next, and in 
response examine agri-food scholarship dealing with alternative food systems, localization and place-based alternatives to "food from anywhere," and the moral economy. They suggest key parameters of a sustainable food system, going beyond environmental sustainability into equity within the present generation and with future generations, new governance systems, and new economic structures. They introduce neoliberalism and "corporate-interest food governance" as key barriers to sustainable food systems, a theme that many of the subsequent chapters and the conclusion pick up. In some ways this book is the foodsecurity counterpoint to Naomi Klein's This Changes Everything: Capitalism vs. the Climate; whereas Klein focuses on climate change as the driver for a new and more sustainable socioeconomic system, Marsden and Morley focus on food security as the driver. Climate change and food security are closely linked, of course.

The second chapter is also a scoping chapter and addresses assessments and reports of food futures, oddly omitting the 2008 IAASTD; the 2009 Agrimonde study; and United Nations studies of the food-environment intersection, such as FAO's multiple studies of organic agriculture and UNEP's 2009 Environmental Food Crisis. This chapter would have benefited from an "assessment of the assessments," or critical analysis and comparison of recommendations from different reports, what has been learned, and the knowledge gaps that remain. Following chapters address more specific topics: European food governance, public procurement, sustainable food supply chains, animal disease regulation, farm animal welfare regulations and market differentiation based on welfare standards, rural-urban linkages, and urban food strategies.

Most chapters are UK-centric, although some examples are included from other places and the chapters on animal disease and animal welfare are explicit comparisons across countries. Despite the focus on British practices, many of the conclusions apply across industrialized countries. The final chapter notes that entry into "post-productivist" agri-food policy has been uneven. This has not happened at the federal level in the United States, so much of the book is not (yet) applicable to U.S. policy, even though alternatives are emerging at state and municipal levels. The chapters do not delve into exactly who is using and benefiting from the alternative mechanisms in the UK or other countries, although the chapter on urban food strategies claims that many of these are focused on the right of every citizen to have access to healthy, nutritious food. While I am aware of "good food" or healthy food for all as a common denominator across urban food strategies, this is not the same as being focused on rights and justice. The question remains whether the many alternative ways of achieving food security more sustainably described in this book are resulting in greater equity and political engagement for disenfranchised or marginalized people, which are among the attributes of sustainable food systems described by the authors. And their applicability in impoverished countries where food insecurity is highest was not a real concern of most chapters. Exploring global feasibility and applications of this "new paradigm" was not a stated intention of the authors, yet they did not limit its scope to Western Europe and industrialized countries.

The book has a few factual errors and out-ofdate figures; for example, chapters 1 and 2 used the FAO's 2009 and 2010 "malnourishment" figures, despite including many later references and even though these figures have been subject to revisions and indicate extreme chronic hunger rather than malnourishment. Another example: Toronto was not the first city to establish a food policy council (p. 189). Yet overall the writing is clean, if somewhat dense for a reader who is not steeped in sociological and political science terminology.

This book would be an interesting supplement to a graduate course in Food Studies that deals with food system governance and agri-food alternatives. Among its strengths are the rich bibliographies, especially of sociological and political science literature in Europe, that accompany each chapter. These offer an intriguing window into British and European scholarship on new possibilities for sustainable food systems. 


\section{References}

Klein, N. (2014). This changes everything: Capitalism vs. the climate. New York: Simon \& Schuster.

McIntyre, B. D., Herren, H. R., Wakhungu, J., \& Watson, R. T. (Eds.). (2009). Agriculture at a crossroads: Synthesis report. Washington, D.C.: Island Press.

Nellemann, C., MacDevette, M., Manders, T., Eickhout, B., Svihus, B., Prins, A. G. \& Kaltenborn, B. P.
(Eds.). (2009). The environmental food crisis - The environment's role in averting future food crises. Arendal, Norway: GRID-Arendal. Retrieved from http://www.grida.no/publications/rr/food-crisis Paillard, S., Treyer, S., \& Dorin, B. (Eds.). (2010). Agrimonde - Scenarios and challenges for feeding the world in 2050. Versailles: Editions Quae. 